\title{
Em busca da saúde: paisagem e doença na história ambiental americana $^{1}$ \\ Gregg Mitman*
}

\begin{abstract}
A mais importante característica de um organismo é aquela capacidade de autorrenovação interna conhecida como saúde.

Existem dois organismos cujos processos de autorrenovação estão sujeitos à interferência e controle humano. Um desses é o próprio homem (medicina e saúde pública). $O$ outro é a terra (agricultura e conservação).
\end{abstract}

Aldo Leopold, A Sand County Almanac

Saúde. Para Aldo Leopold essa era a função mais vital dos organismos vivos. A terra, assim como o corpo humano, argumentava Leopold, estava sujeita a distúrbios que resultavam em doenças e possuia capacidade fisiológica de auto-renovação quando perturbada. Suas alusões à saúde da terra em $A$ Sand County Almanac [Um almanaque de Sand County], um texto valorizado por lançar as bases do biocentrismo, são surpreendentes. ${ }^{1}$ Como podemos extrair sentido dessa aparentemente incongruente mistura de medicina a mais antropocêntrica das artes científicas - com conservação - esfera e valores os quais Leopold esperava basear principalmente na natureza não humana? Por que, se a natureza era tão central ao pensamento e prática conservacionista de Leopold, não tem sido um objeto mais central da história ambiental? ${ }^{2}$

Talvez seja porque nós tão prontamente aceitamos as dicotomias humano versus natureza, urbano versus rural, local versus global - que têm estruturado o pensamento e o debate ambiental e as narrativas históricas que escrevemos sobre eles. Uma consequência é que as preocupações com os recursos naturais são separadas cronológica, conceitual e espacialmente daquelas da saúde humana. Vamos considerar, por exemplo, os temas prin-

\footnotetext{
* PhD em História da Ciência. Professor de História da Ciência, História Médica e Estudos da Ciência e Tecnologia na Universidade de Wisconsin-Madison, EUA. E-mail: gmitman@med.wisc.edu

${ }^{1}$ Este artigo intitulado "In search of health: landscape and desease in American Environmental History" foi publicado originalmente no periódico Environmental History; 10, 2; Apr 2005; pp. 184-210. Tradução realizada por Silvana Prado.
} 
cipais que são trabalhados nos cursos de graduação e os textos que tratam de um aspecto importante da história ambiental americana: a emergência do ambientalismo americano. No final dos séculos XIX e XX, o movimento conservacionista era principalmente liderado pelos profissionais urbanos das classes média e alta, cujo foco no gerenciamento eficiente ou preservação das florestas, rios, peixes e vida selvagem da nação e para usos recreacionais levou ao estabelecimento de parques e reservas florestais, e das agências estaduais e federais de regulamentação e controle dos recursos naturais. Depois da Segunda Guerra Mundial, padrões de vida em elevação levaram um crescente número de americanos a defender as preocupações ambientais associadas à saúde e bem estar que formaram as sementes do movimento ambiental dos anos $60 .^{3}$ Assim vai a história.

$\mathrm{Na}$ última década, os historiadores ambientais urbanos têm tentado deslocar essa visão predominante. O escopo histórico do ambientalismo americano, uma vez focado na preservação da vida selvagem e no gerenciamento dos recursos naturais, foi expandido para incluir as dificuldades dos cidadãos e cientistas no combate aos perigos ambientais da cidade e do local de trabalho. Na batalha que os Reformadores Progressistas, como Alice Hamilton, lançaram contra a poluição e o lixo na cidade industrial, a saúde emergiu tanto como uma preocupação médica quanto ambiental. ${ }^{4}$ Mas mesmo com essa muito necessária perspectiva revisionista, a cidade permanece distanciada do campo, a saúde é um tema que ocupa um lugar distante da conservação. E a história das ideias, valores e movimentos sociais ambientais nos Estados Unidos acontece em um vácuo relativo, fortemente isolado dos movimentos de ideias científicas, pessoas, flora e fauna do mundo todo.

Que tal se tomássemos a metáfora de Leopold de saúde da terra não apenas como um floreio retórico, mas sim com sua base nas relações históricas, materiais e sociais de conhecimento e lugar? Como poderia um foco na saúde revelar novos padrões na paisagem histórica do ambientalismo americano, onde os espaços entre saúde e conservação, humano e natureza, cidade e campo, história ambiental européia e americana não parecem tão grandes?

Este artigo oferece um levantamento historiográfico preliminar sobre paisagem e doença na história ambiental americana. É uma busca por lugares passados onde a saúde habitava visivelmente a paisagem e moldava as interações humano-ambiente. Seja através da experiência íntima de doença e lugar ou através do conhecimento científico captado das comunidades ecológicas, concepções de saúde têm sido integrais à experiência e ao 
entendimento ambiental. Conforme reconhecido por Leopold, a saúde é um conceito relacional. A saúde adquire significado apenas em virtude das relações entre os organismos vivos - sejam esses as células do corpo humano ou as espécies de uma comunidade biótica - e seus ambientes. O conhecimento também é um conceito relacional. É o produto de uma rede de relações materiais, sociais e simbólicas entre os atores humanos e não humanos. Ao atravessar as categorias do humano e não humano, a saúde oferece meios úteis para repensar a natureza e como passamos a conhecer o mundo natural. $^{5}$

\section{Natureza que cura}

Durante os anos 30, quando Leopold começou a introduzir as metáforas de saúde e doença em sua abordagem ecológica da conservação em desenvolvimento, biólogos e médicos, tanto nos Estados Unidos quanto em outros países, falavam de uma "crise" percebida na medicina. O sucesso inicial da teoria dos germes causadores de doenças no final do século XIX tinha dominado a compreensão da etiologia e patologia das doenças, localizando a doença em uma causa única, o micróbio. Mas um número de fatores durante os anos entreguerras - incluindo a pandemia de gripe de 1918-1919, as doenças tropicais que minavam os esforços de desenvolvimento, a predominância do laboratório sobre o cuidado no leito e a crescente especialização médica, apenas citando alguns fatores - despertaram um interesse renovado em uma abordagem mais integrada e às vezes até mesmo holística ao entendimento da doença, na qual a relação entre o indivíduo e seu ambiente recuperaram a importância. ${ }^{6}$ Ao invés de médicos heróis como Robert Koch e Louis Pasteur, alguns biólogos dos anos entreguerras voltavam-se para o antigo médico grego Hipócrates, a quem eles creditavam o conceito introdutório da saúde como um estado de equilíbrio entre o organismo e seu ambiente em geral. Conforme explicado no tratado de Hipócrates, Ares, Águase Lugares, a doença resultava de um desequilíbrio ou distúrbios no estado natural do corpo como se encontrava no complexo ambiental de fatores físicos e sociais que governavam a vida do paciente como um todo. Em etiologia e patologia, a visão hipocrática permanecia em um contraste marcado com a teoria bacteriológica surgida mais tarde que afirmava que a doença poderia ser prontamente rastreada até um agente externo único.

Nessa retomada neo-hipocrática, a saúde tornou-se definida através das funções normais de auto-regulagem do corpo, a patologia não era mais do que uma extensão da fisiologia. Esse entendimento funcional da doença 
omitia a tão fortemente enraizada divisão humano/natureza. Todos os organismos vivos - plantas, animais e humanos - e todas as organizações vivas - células, indivíduos, populações, comunidades e sociedades - compartilhavam propriedades de auto-regulação e manutenção. Se alguém estivesse escrevendo sobre doenças do corpo, terra ou sociedade, os mesmos princípios biológicos de equilíbrio se aplicavam.

O renomado fisiologista de Harvard, Walter B. Cannon, prontamente movimentou-se entre a fisiologia do corpo e a política do corpo em seus escritos, assim como muitos outros biólogos nos anos entreguerras, incluindo Leopold. A facilidade com que eles o fizeram foi grandemente favorecida por uma concepção de patologia informada não pela bacteriologia, mas pela fisiologia. Baseado em sua pesquisa sobre a regulação fisiológica do sistema nervoso simpático nos anos 20, Cannon introduziu o conceito de homeostase para se referir à condição de estabilidade, ou equilíbrio controlado, que o corpo constantemente restabelece em suas interações com as influências perturbadoras dos ambientes externos e internos. O pâncreas, por exemplo, monitora os níveis de glicose no sangue, alterando a concentração de insulina ou hormônios glucagon para manter um equilíbrio dinâmico entre os níveis de açúcar no sangue e manter as demandas energéticas do corpo. A inabilidade de produzir insulina perturba esse sistema auto-regulatório; uma desordem no funcionamento normal constitui a doença conhecida como diabetes. ${ }^{7}$

No meio da depressão, quando o governo, a indústria e as universidades se preocupavam em como controlar a grande flutuação econômica, Cannon sugeriu a Wallace Donham, diretor da Harvard Business School, que "os mecanismos para estabilização que são usados no corpo fisiológico devem também estar disponíveis ao corpo político." ${ }^{8}$ No epílogo de seu conhecido livro de 1932, The Wisdom of the Body [A Sabedoria do Corpo], Cannon reflete sobre que lições podem ser aprendidas do organismo animal para curar a economia política doente da nação. A sociedade ainda estava em um estágio "relativamente rudimentar de desenvolvimento", Cannon argumentou, semelhante àquele dos anfíbios cuja falta de termoregulagem interna tornou-os muito mais dependentes do ambiente externo do que os mamíferos. Para alcançar maior independência e estabilidade, os Estados Unidos precisariam sacrificar sua fidelidade ao mercado livre. Assim como o organismo demonstra "controle especialmente organizado... para preservar a constância da matriz fluida", a sociedade deveria estar investida do "poder de limitar a produção de bens", deixando de lado os estoques, e "requerendo reservas de 
pagamento para uso futuro" no caso de "perturbação social". ${ }^{9}$ Cannon não procurava estabilidade social através de "um sistema social fixo e rígido" tal como o comunismo ou socialismo. Um partidário da resistência anti-Franco na Espanha, ele previa uma democracia social liberal, ao manter as políticas econômicas do New Deal , nas quais "funções industriais e comerciais adaptáveis asseguram o suprimento contínuo das necessidades humanas elementares." 10

Três anos após a publicação da obra de Cannon, A Sabedoria do Corpo, Leopold em um discurso intitulado "Patologia da Terra" apoiou-se em um discurso neo-hipocrático semelhante que equiparava o desequilíbrio patológico com o funcional para criar uma mensagem poderosa que ele acreditava ressoaria em sua audiência e esperava que os acordasse para uma nova relação ética com a terra. Falando no capítulo Sigma XI da Universidade de Wisconsin um dia após o Domingo Negro - quando nuvens de poeira eclipsaram o sol da tarde nas Grandes planícies ressecadas e obstruíram os pulmões humanos, o gado e a vida selvagem, durante um período de depressão econômica que ameaçava a vida da nação como um todo - Leopold sugeriu que "a sociedade tinha desenvolvido um ajuste instável ao seu ambiente, no qual ambos deveriam eventualmente sofrer dano ou mesmo ser arruinados. Considerando sociedade e terra coletivamente como um organismo, esse organismo tinha repentinamente desenvolvido sintomas patológicos, isto é, autoacelerando ao invés de autocompensar partidas do funcionamento normal". ${ }^{11}$ Em Um almanaque de Sand County, Leopold daria corpo a essas ideias de saúde da terra (capacidade de autorrenovação) e doença da terra (um sintoma de desorganização) de formas que revelariam seu débito a um modelo hipocrático de doença que circulava entre as disciplinas biológicas com uma disposição para uma concepção fisiológica da vida. Por exemplo, seu argumento pela vida selvagem enquanto fornecedora de "uma base de dados de normalidade, um quadro de como a terra saudável se mantém enquanto organismo", incorporada a um entendimento funcionalista do normal e do patológico que informava as ciências da economia dos séculos XIX e XX: fisiologia (economia animal), ecologia (economia da natureza), e economia política. Nessa perspectiva, a saúde se movia prontamente através da divisão humano/natureza. ${ }^{12}$

Embora a analogia do organismo social invocada por Cannon e Leopold tenha sido usada ao longo da primeira metade do século XX para apoiar uma variedade de visões políticas - desde o Apartheid na África do Sul, ao fascismo na Alemanha e a democracia nos Estados Unidos - embutida nela 
estava a suposição de que a natureza oferecia diretrizes e prescrições morais para a sociedade humana. ${ }^{13}$ Uma vez mais Cannon ligou esses apelos à sabedoria e poderes curativos da natureza a Hipócrates, que introduziu a "ideia de que a doença é curada por poderes naturais, por uma vis medicatrix naturae", que "implica a existência de agências que estão prontas a operar corretivamente quando o estado normal do organismo é perturbado". ${ }^{14}$ Escrevendo nos anos 30, o historiador italiano da medicina e médico Arturo Castiglioni viu em sua concepção hipocrática uma visão do "homem como uma parte indestrutível do cosmo, ligado a ele e sujeito às suas leis." Ele contrastou essa com outra tradição filosófica, a de Galen, que ele associou com a medicina experimental moderna, na qual a doença era considerada "como um fato exterior e incidental que deve ser conquistado: uma batalha entre a causa patogênica e o médico que tenta dominá-la." ${ }^{15}$ Como observado mais tarde pelo patologista comparativo do Instituto Rockefeller e ambientalista René Dubos, o médico hipocrático "deveria ser qualificado em natureza" e "não deveria esquecer que os distúrbios em qualquer órgão correspondem a distúrbios da pessoa como um todo." "Para curar até mesmo um olho," Dubos argumentava, "deve-se curar a cabeça e até mesmo o corpo todo."16

A crença de que os poderes curativos de um médico derivavam dos próprios processos da natureza era uma parte fundamental da sua visão neo-hipocrática. Essa foi uma lição que Leonard percebeu se aplicar à arte e à ciência da conservação. Na verdade, essa utilidade dual pode ter sido uma de suas atrações. Enquanto Leopold reconhecia em seu discurso, "Patologia da Terra", que a ciência poderia "inventar mais e mais ferramentas, as quais poderiam ser capazes de extrair vida mesmo de um campo arruinado" ele, por sua vez, não tinha interesse em ser "uma célula naquele tipo de política do corpo". ${ }^{17}$ Isso sugere que a mudança nas atitudes de Leopold de um etos utilitário e gerencial nos seus primeiros anos no Serviço Florestal dos Estados Unidos a um ponto de vista ecológico, os primeiros sinais do que se revela na "Patologia da Terra", foi acompanhada por um entendimento mais holístico e funcional dos organismos e doenças intimamente ligados ao pensamento hipocrático. "Em geral," Leopold escreveu no Um almanaque de Sand County, "a tendência da evidência indica que na terra, assim como no corpo humano, os sintomas podem estar em um órgão e a causa em outro. As práticas que agora chamamos de conservação são, em grande medida, o alívio local da dor biótica. Elas são necessárias, mas não devem ser confundidas com cura. A arte de tratar a terra está sendo praticada com vigor, mas a ciência da saúde da terra ainda está para nascer". ${ }^{18}$ 
Ao curar a natureza, a tarefa do ecologista, como aquela do médico hipocrático, era restaurar o equilíbrio ao auxiliar os processos estabelecidos na natureza. Os biólogos tinham encontrado em uma concepção fisiológica do normal e do patológico um discurso comum nos anos entreguerras que permitiam uma troca de ideias mais livre por meio das ciências da vida, da fisiologia humana ao gerenciamento da vida selvagem, e uma integração dos níveis biológicos de organização, das células humanas às comunidades ecológicas.

\section{Ecologias da doença}

As ideias sobre saúde da terra que Leopold empregou em seus esforços para estabilizar e gerenciar a economia integrada de plantas, pessoas, animais e o solo em Wisconsin não eram o produto de um indivíduo solitário, mas sim de uma rede transnacional de instituições, cientistas e economias políticas. Anos atrás, Richard Grove primeiramente lembrou os historiadores ambientais americanos que as atitudes conservacionistas não eram endêmicas à paisagem norte-americana. Em Green Imperialism [Imperialismo Verde], Grove ofereceu um relato convincente de como as ideias ambientais iniciais dependiam das experiências dos naturalistas coloniais, agentes médicos e comerciantes que, em sua luta para tornar as ilhas paradisíacas economias produtivas, testemunharam o impacto devastador que a degradação ambiental tinha causado sobre as comunidades naturais e humanas. Se tínhamos sido lentos ao integrar a história da conservação americana com redes mais globais de troca, isso é porque nós falhamos em ver a disciplina profissional da ecologia como um local de comércio internacional. ${ }^{19}$ As ideias científicas e as atitudes ambientais podem ter sido localizadas em paisagens históricas particulares, mas foram também móveis, adaptáveis a novos ambientes. A noção de saúde da terra de Leopold é um exemplo. Ela pode ter florescido no solo do ambientalismo americano, mas sua forma embrionária se transformou em outro ambiente: um clima da era da Depressão, de crise e instabilidade, um renascer neo-hipocrático da medicina que fortaleceu os laços entre patologia e fisiologia, e uma preocupação mais generalizada por estabilizar e aumentar a produtividade da economia da natureza.

Como presidente do Comitê do Cervo dos Cidadãos de Wisconsin e membro da Comissão de Conservação, Leopoldo esforçou-se nos anos 40 para tratar do problema do crescimento populacional de cervos em Wisconsin. Ao concentrar-se em uma espécie única ao invés de todo o ecossistema, os gerentes de caça do passado demonstravam um tipo de arrogância inte- 
lectual que levou bacteriologistas ignorantes da ecologia do corpo a acreditar, por exemplo, que o isolamento do bacilo da tuberculose levaria à erradicação da doença. Faltava visão ecológica a ambos. A suposição de que "a atividade predatória humana com o rifle é o equivalente biótico da atividade predatória do lobo" tinha levado a perturbações violentas no equilíbrio das relações das comunidades. Os ciclos de expansão e quebra de populações de cervos, que Leopold acompanhava em Kaibab, na reserva George em Michigan, na Península inferior de Michigan e na Pensilvânia colocavam em risco não apenas os rebanhos de cervos, mas a saúde e a capacidade produtiva da terra. Minimizar essas "irrupções" nos ciclos populacionais tornar-se-ia o maior esforço em auxiliar a estabilização tanto da economia da natureza quanto a indústria de caça e turismo em Wisconsin. ${ }^{20}$

Embora com raízes na paisagem regional de Wisconsin, as ideias e ferramentas que Leopold utilizava estavam imbricadas em condições materiais, culturais e político-econômicas de escala global; elas eram parte do fluxo material transnacional de capital, produtos, pessoas e regimes de acumulação que estruturam o conhecimento e o lugar. ${ }^{21} \mathrm{O}$ entendimento de Leopold da dinâmica dos ciclos de população e seu uso do termo irrupções devem muito a Charles Elton, um líder em ecologia animal britânico dos anos entreguerras, que se tornou o guia e conselheiro de Leopold em assuntos de ecologia profissional e um querido e confiável amigo. Os dois se conheceram em 1931 na Conferência Matamek de Ciclos Biológicos, fundada pelo rico negociante americano Copley Armory, que acreditava que os cientistas com um conhecimento íntimo dos ciclos populacionais na economia da natureza poderiam ser capazes de aconselhar os ciclos flutuantes de negócios que perturbavam as economias nacionais. Consultor da empresa Hudson Bay e do Conselho de Marketing Empire, Elton era um especialista nas dinâmicas de crescimento dos parasitas, pestes e populações selvagens que se provaram um valioso bem econômico na recuperação da indústria de pele e na exploração e desenvolvimento de recursos naturais nas colônias britânicas em expansão.

$\mathrm{Na}$ Inglaterra, a ecologia tinha se tornado firmemente imbricada com a economia do império. Na verdade, os ambientes coloniais se provaram instrumentais no desenvolvimento das ideias ecológicas. ${ }^{22} \mathrm{Na}$ África tropical, por exemplo, as doenças endêmicas tais como a malária e a doença do sono representaram obstáculos significativos à colonização europeia. Conforme as esperanças iniciais de erradicação se esvaneceram, os agentes do governo, epidemiologistas e especialistas em medicina tropical começaram, nos 
anos 20 , a adotar um entendimento mais complexo, ecológico das relações entre ambiente e doença. A entomologia médica, parasitologia, ecologia da população e da comunidade e a ciência veterinária, todas se tornaram relevantes para o entendimento de como fatores bióticos e abióticos regulavam as dinâmicas de interações hospedeiro-parasita e a distribuição e abundância das doenças tropicais.

Elton estava no centro dessa mudança, e seu trabalho sobre ecologia da doença foi sem dúvida instrumental na adoção crescente de Leopold de uma visão fisiológica na qual a doença significava uma perturbação do funcionamento equilibrado da comunidade como um organismo. As relações entre conservação e saúde que Leopold articulou não começaram a surgir apenas no solo americano. ${ }^{23}$

Professor de zoologia na universidade de Oxford e chefe do Bureau de Populações Animais, Charles Elton gastou seus dias bem limitados de pesquisa de campo na fria tundra, não nos tórridos trópicos. Mas sua compreensão da dinâmica dos alimentos e dos ciclos de população animal foram facilmente traduzidos para outras comunidades diferentes de animais. ${ }^{24} \mathrm{Em}$ seu clássico texto Animal Ecology [Ecologia Animal], Elton explicou as relações econômicas e sociais dentro da comunidade animal que regulavam os números de animais. Princípios funcionais gerais relacionados a ciclos de alimentos e a pirâmide dos números que Elton apresentou se tornaram parte do vocabulário de Leopold, assim como o entendimento de Elton da comunidade como um complexo, uma teia precária de interações. Um sistema de controle e equilíbrio mantinha a comunidade em um equilíbrio dinâmico; qualquer distúrbio no ambiente poderia levar a irrupções violentas em uma certa população animal com consequências imprevisíveis.

Elton estava particularmente interessado em doenças epizoóticas como uma força que governava a estrutura da comunidade. "Doenças causadas por diversos animais parasitas", ele ponderava, não eram mais "do que um rompimento dos parasitas do controle do hospedeiro e crescente em grande velocidade." "Malária, doença do sono, todas essas doenças", Elton sugeriu, "são o resultado de um super crescimento de parasitas, assim como as pragas de ratos são o resultado de um super crescimento dos ratos". ${ }^{25} \mathrm{~A}$ doença deveria ser vista como um sintoma, não uma causa, de desequilíbrio nas relações entre os organismos e seus ambientes. A visão de Elton ressoava com o que o seu mentor Julian Huxley observou como uma tendência na medicina que se afastava do foco nos germes e sua erradicação para se concentrar na doença como um "fenômeno da biologia geral, em cuja causa 
a constituição e fisiologia do paciente e os efeitos do ambiente tinham tanta importância quanto os parasitas específicos". ${ }^{26}$

Como a diáspora ecológica das espécies nativas em novas terras aumentou, Elton acreditava que as comunidades animais e humanas enfrentavam uma crescente ameaça de doenças epidêmicas; ele foi rápido ao explorar esse medo para reforçar a disciplina da ecologia. No final do seu livro de 1941, Voles, Mice, and Lemmings [Ratos, Camundongos e Lêmingues] - um estudo denso e extenso da história ambiental da praga de ratos e camundongos na Europa aliado ao seu trabalho sobre a ecologia dos ciclos de vida selvagem no ártico canadense - Elton retratou o norte longínquo como uma região na qual condições de vida precárias, doenças epidêmicas em cães e raposas e abastecimento de alimento humano e natural flutuante ameaçavam a estabilidade econômica e ecológica. Era um desastre eminente que Elton acreditava merecer "muito dinheiro, pessoal científico treinado, estações de campo, e continuidade de atenção como tem sido dado ao estudo da malária... ou da doença do sono" ${ }^{27}$ Vinte anos depois, em seu importante livro The Ecology of Invasions by Animals and Plants [A ecologia das invasões por animais e plantas], Elton retornou a temas semelhantes. "A mistura de milhares de tipos de organismos de diferentes partes do mundo", ele argumentava, estava "iniciando terríveis deslocamentos na natureza" que criavam condições favoráveis ao início de doenças e ameaçavam nossos "recursos vivos e saúde econômica". ${ }^{28}$

Se tal apelo provou-se útil em conseguir suporte para o Bureau das Populações Animais de Elton, foi no sul e não no norte que os princípios ecológicos que Elton e outros desenvolveram pareceram manter a promessa maior de aumento da estabilidade econômica e saúde do império Britânico. Na introdução do livro de Elton, Animal Ecology [Ecologia Animal], Julian Huxley advertiu que "se o homem quiser fazer valer sua predominância nessas regiões do globo cujo clima garante uma vantagem inicial aos seus rivais de sangue frio, a peste da planta e mais ainda, o inseto," a "aplicação apropriada do conhecimento científico" seria necessária. ${ }^{29}$ Conforme Helen Tilley demonstrou, Huxley retornou de suas viagens de 1929-1930 no leste da África, representando o Comitê Consultivo da Colônia sobre Educação Nativa, "cativado pelas questões da doença do sono e dos tripanossomas africanos" e convencido da importância da pesquisa ecológica em "espécies vetoras e parasitas em relação aos seus hospedeiros e ambientes". ${ }^{30}$ Acreditando que a ecologia "estava destinada a um grande futuro", ele e Elton pressionaram no início dos anos 30 para o estabelecimento de um Bureau da Ecologia Africana 
que integrasse pesquisa em ecologia animal, médica e humana como suporte do desenvolvimento econômico. ${ }^{31}$ Embora o Bureau nunca tenha se tornado realidade, a perspectiva ecológica defendida por Huxley e Elton tornou-se parte dos esforços administrativos na colônia. De 1927 a 1931, por exemplo, o ecologista de plantas sul-africano John C. Phillips, enquanto diretor assistente do departamento de pesquisa em tsé-tsé no território Tanganyika, abordou o problema dos tripanossomas africanos como um problema das relações entre comunidades nas quais todos, humanos, animais, plantas e parasitas, tinham um papel..$^{32}$

A doença estava então no nexo ecológico das comunidades animal e humana. Longe de reforçar uma divisão entre humanos e natureza, a ecologia da doença, em todas as suas formas, necessitava a inserção dos humanos de volta ao seu ambiente. Os humanos não eram mais do que uma espécie em uma rede de relações econômicas e sociológicas estruturadas em torno das relações entre presa e predador e entre hospedeiro e parasita. Nos anos durante após a Segunda Guerra Mundial, quando o advento das drogas de sulfanilamida parecia marcar o triunfo dos humanos contra a natureza, escritores como F. Macfarlane e René Dubos (que, assim como Elton, consideravam "a doença uma manifestação da interação dos seres vivos") alertavam para tal otimismo tecnológico. Em suas mentes, a história da doença e da civilização humana em sua longa duração apenas reforçava a necessidade de mais consciência dos humanos como sendo nada mais do que um entre muitos atores do teatro ecológico na peça evolucionária da vida. ${ }^{33}$

Poucos historiadores ambientais reconhecem o débito que uma geração de estudos da história da doença, meio ambiente e imperialismo tem para com esse trabalho inicial sobre a ecologia da doença. ${ }^{34} \mathrm{O}$ livro pioneiro de William McNeill, Plagues and Peoples [Pragas e pessoas], descreve o avanço histórico e queda das civilizações humanas como dependente das perturbações e ajustes no equilíbrio ecológico entre os humanos e as doenças infecciosas. Conforme suas notas de rodapé revelam, ele importou esse modelo diretamente de estudos científicos prévios sobre a ecologia da doença. Da mesma forma, trabalhos como o de Alfred Crosby, The Columbian Exchange [A troca colombiana] e Imperialismo ecológico, ou de Jared Diamond, Armas, germes e aço, retratavam a história da expansão européia como uma história da invasão ecológica: Os perdedores foram vítimas de uma mão biológica operada pela evolução que não poderiam competir com sucesso em um jogo de guerra..$^{35}$ Mesmo o retrato contínuo dos derrotados como limitados por seu ambiente nessas histórias ecológicas do império deveriam provocar uma 
reflexão mais crítica sobre como a história ambiental se apropria do conhecimento científico para conferir agência à natureza.

Para um campo no qual o local tem figurado tão centralmente em suas narrativas, porque a história ambiental tem sido tão reticente em ver o conhecimento científico sobre a natureza como um produto histórico de certas relações materiais e sociais? A economia política, por exemplo, é tanto uma força na produção do conhecimento científico, quanto o é na transformação das paisagens. Se os estudos baseados em estudos das ciências nos ensinaram alguma coisa nas duas últimas décadas, foi a importância de perceber como as formas de conhecimento são criadas e sustentadas pelas circunstâncias econômicas, políticas e culturais. ${ }^{37}$ A economia do império nutriu e sustentou a abordagem integrada e funcionalista da ecologia humana e animal de Elton. Conforme Warwick Anderson argumentou, “o impacto persistente das políticas de desenvolvimento colonial" e "os efeitos de longa duração na agricultura e reassentamento humano" ofereceram um ambiente particularmente propício para uma abordagem biológica das doenças infecciosas, mais atento às relações entre doenças, ambiente e processos evolucionários. ${ }^{38}$ Mas a ecologia da doença também emergiu em um período quando as perspectivas dos esforços britânicos na exploração e desenvolvimento da África pareciam menos promissores. As narrativas científicas da ecologia da doença ofereceram um alerta no qual a biogeografia dos trópicos impunha limites sobre as sociedades humanas. Desde o século XVII, a ciência tem servido como uma ferramenta importante ao império; nós deveríamos ser cautelosos quando ela é da mesma forma utilizada como um pilar da história determinística do império.

Os Estados Unidos não ficaram imunes às suas próprias ambições imperiais. Na América Latina, nas Filipinas, no Sul da Ásia, na Libéria, os Estados Unidos utilizaram capital, trabalho, ciência e tecnologia para reconfigurar as relações de ecossistemas - para criar novas naturezas e novas economias. Em um artigo publicado na Environmental History, Paul Sutter ofereceu uma visão altamente informativa de como os historiadores ambientais americanos podem se beneficiar de estudos sobre história ambiental não-americana atenta às relações coloniais e imperiais. ${ }^{39} \mathrm{~A}$ paisagem e a doença são temas importantes. Na conquista e ocupação das Filipinas, o império da banana da United Fruit Company, na construção do canal do Panamá, e no estabelecimento da Firestone Plantations Company na Libéria, a doença tem um papel importante na produção histórica da natureza. ${ }^{40}$ Mas que tipo de papel? 
Diferentemente do estudo passado que se baseava na ecologia da doença para dar vida aos micróbios como agentes universais do império, precisamos examinar mais criticamente as formas nas quais esses atores não humanos se formaram e adquiriram agência quando a doença se torna uma categoria analítica mais central dentro da história ambiental. A ação dos atores não humanos, como ratos, piolhos ou pulgas estão conectados às, e não independentes das, histórias da produção do conhecimento através das quais tais objetos ganham novo significado e poder no mundo. 0 mosquito, Aedes aegypti, por exemplo, teve uma relação e lugar diferentes na paisagem caribenha depois que Walter Reed e a Comissão de Febre Amarela do Exército Norte-Americano o identificaram como vetor da febre amarela. Apenas em relação a Reed e ao aparato técnico da medicina tropical o Aedes aegypti foi transformado em uma força poderosa da natureza, que mobilizou a expertise dos engenheiros sanitários, médicos e entomologistas e vastos recursos do governo dos Estados Unidos. "Pode o mosquito falar?" pergunta Timothy Mitchell em Rule of Experts [Regra dos especialistas]. Sua resposta fornece uma análise histórica convincente das interações entre barragens, parasitas do sangue, químicos sintéticos, guerra mecanizada e fome no estado do Egito que evita qualquer relato simples de agência não humana. "O que é chamado de natureza ou mundo material", Mitchell argumenta, "move-se como o plasmódio para dentro e para fora das formas humanas, ou ocorre como arranjos, como o rio Nilo, que são tanto sociais quanto naturais, técnicos bem como materiais". ${ }^{41}$ Seu relato desafia profundamente os historiadores ambientais a ver padrões diferentes de relação entre paisagem e doença. Ao invés de considerar o mosquito como uma entidade cuja ação sobre a paisagem existe para além dos humanos, devemos na verdade considerar seu existir e ação como dependentes de uma rede relacional de pessoas, coisas e forças em qualquer momento histórico no tempo. A natureza é um resultado, não a causa das mudanças na terra. Assim como a saúde, ela é um produto das inter-relações entre os atores humanos e não humanos.

\section{A purificação da natureza}

As redes nas quais a noção de saúde da terra de Leopold se originou e floresceu se estenderam não apenas através de diferentes disciplinas biológicas e diferentes escalas espaciais, de questões de recurso natural regional a preocupações econômicas mais globais, elas também se estenderam em direção ao passado. A retomada neo-hipocrática, da qual Leopold fez parte, teve raízes profundas na paisagem histórica da América. A fluidez entre or- 
ganismos e ambiente, central a uma noção de saúde como equilíbrio fisiológico, pode parecer estranha a uma perspectiva informada pela biomedicina contemporânea, mas a permeabilidade do corpo e do lugar foi integral na experiência vivida no século XIX pelos colonizadores americanos. Um argumento de Leopold pela preservação da vida selvagem foi pela perpetuação de "habilidades mais viris e primitivas nas viagens e subsistência pioneiras" que faziam parte da experiência daqueles colonizadores. ${ }^{42}$

Terra "saudável", "lugares doentes" e "salubridade", conforme Conevery Bolton Valençius expressou, carregam a experiência dos viajantes no encontro das novas terras. Seu bem estar pessoal e o da nação dependiam dos ares, das águas e dos lugares. ${ }^{43} \mathrm{O}$ conselho de Hipócrates aos médicos da antiga Grécia para conhecer a "influência do clima, suprimento de água e a situação da saúde" foi uma lição incorporada nos pensamentos, crenças e práticas daqueles que se confrontaram com uma nova vida na fronteira ocidental. ${ }^{44}$

"Euro-americanos", observa Linda Nash, "avaliavam a nova paisagem não apenas em termos do seu potencial de recursos ou qualidades estéticas, mas através dos seus efeitos sobre a saúde." Temperatura e altitude, vegetação e tipo de solo, direção do vento e umidade, nuvens e mudanças de estação eram importantes medidas barométricas de saúde ${ }^{45}$ Enquanto Joseph Henry, o primeiro secretário do Instituto Smithsonian, abasteceu os voluntários através do território em expansão com termômetros, barômetros e higrômetros para medir e registrar relatórios detalhados mensais do clima que eram centralmente enviados por telégrafo a Washington, tal equipamento científico no início apenas reforçou a precisão do corpo como um instrumento de auto-registro - um barômetro preciso e um calendário sazonal - de mudança ambiental. ${ }^{46}$ Mudança de lugar precipitava mudança corporal manifestada por meio da doença. Adaptação à sazonalidade, o processo pelo qual o corpo se habituava a um novo clima e topografia, levava tempo. Para aqueles que conseguiam sobreviver, o retorno à saúde significava uma restauração do equilíbrio entre o corpo e a terra.

Fora dessa experiência coletiva de corpos e instrumentos, um atlas de saúde e lugar emergia na América pré-guerra civil que moldava a prática médica, os padrões de assentamento e a identidade regional. A Systematic Treatise, Historical, Etiological, and Practical, on the Principal Diseases of the Interior Valley of North America [Um Tratado sistemático, histórico, etiológico e prático, sobre as principais doenças no interior do Vale da América do Norte], escrito pelo médico de Cincinnati Daniel Drake, foi o primeiro desses 
atlas. Seu levantamento abrangente de dois volumes dos padrões distintivos de doenças como a malária, tifo, febre amarela e outras doenças era uma fonte de conhecimento sobre geografia física, clima, recursos minerais, história natural, doenças, costumes e hábitos das pessoas que ocupavam "a grande região entre montanhas" entre as Rockies e as Alleghenies, confrontada ao norte pelo mar Polar e ao Sul pelo Golfo do México. Na preocupação do século XIX com a geografia médica, o conhecimento do corpo e do meio ambiente andavam de mãos dadas. ${ }^{47}$

Embora os estudiosos tenham começado a documentar como eram as percepções integrais de ambiente e doença para a colonização, exploração e desenvolvimento da fronteira do oeste, ainda temos que explorar por completo até que ponto a saúde deu formato às interações humano-ambiente e o desenvolvimento econômico regional através da paisagem norte americana. ${ }^{48}$ Algumas áreas do país, como o Central Valley na Califórnia, com seu calor e variações diárias de temperatura, baixa elevação, neblina sazonal densa e ventos intoxicantes, pareciam portos naturais de "vapor inescrutável" ou "miasmas", suposta origem da febre amarela, tifo e várias outras febres intermitentes e remitentes. O cultivo através da agricultura poderia livrar a terra de seus atributos doentes e torná-la uma região econômica vital, mas as ansiedades da fronteira tinham que ser primeiramente superadas, os corpos acostumados às estações e a terra transformada. ${ }^{49} \mathrm{Em}$ contraste, a providência tinha dotado a região montanhosa do Colorado com uma natureza de atmosfera saudável e abundante em recursos. Conforme os promotores da linha férrea e os desenvolvedores das cidades proclamavam, a região de Rocky Mountain, onde o ar não continha "a súbita mancha da malária" e a alta altitude e o sol brilhante revigoravam os corpos exaustos, era, por sua própria natureza, destinada à grandeza. ${ }^{50}$

No final dos anos 1800, quando a base da população dos Estados Unidos mudou-se das áreas rurais aos centros metropolitanos com o advento da industrialização, as propriedades curativas da natureza também começaram a mudar. Na América anterior à guerra civil, lugares doentes e insalubres eram comuns; nem toda natureza não humana era benéfica à saúde. Mas a crescente condição de aumento da população das cidades americanas, a imundície e mau cheiro das ruas e as súbitas epidemias de cóleras, febre tifóide e outras doenças infecto contagiosas sugeriam que a ameaça real à saúde era a natureza da cidade, feita pelas mãos humanas. A introdução da teoria do germe da doença nos anos 1880, e a alegada revolução bacteriológica que seguiu os seus passos, apenas reforçavam essa visão. Nos espa- 
ços urbanos da América, o indivíduo, não o meio ambiente, crescentemente tornou-se o augúrio da doença. O comportamento individual, o histórico de família, o status econômico e os costumes e hábitos de determinados grupos étnicos sofreram crescente escrutínio dos oficiais de saúde pública no combate às doenças da cidade..$^{51}$

Com a expansão da industrialização, imigração crescente, e o fechamento da fronteira, os americanos vieram a considerar a natureza não como parte deles mesmos, mas como um lugar à parte da decadência e da deterioração das paisagens urbanas e dos corpos humanos que as habitavam. Como a mudança de conceitos de saúde e doença ajudaram a reforçar essa divisão entre humanos e natureza, cidade e interior, que dominou a historiografia do ambientalismo americano, merece alguma investigação. Não é uma coincidência, entretanto, que essa separação tenha ocorrido ao mesmo tempo em que as relações íntimas, porosas e complexas entre corpos e paisagens estavam se tornando menos fluidas e o entendimento médico crescia investigando a doença não como um desequilíbrio entre o organismo e seu ambiente, mas como um produto dos micróbios infecciosos carregados pelos humanos, e como um resultado do ambiente degenerado criado pela civilização urbana. Com a disseminação da civilização, a doença emergente do fim do século, a natureza veio a ocupar uma paisagem mais distante e pura dos lugares onde os humanos cada vez mais desenvolviam suas atividades e viviam.

Embora a "teoria do germe, e mais geralmente a doutrina da etiologia específica da doença", possa ter quebrado "o encanto da doutrina hipocrática", conforme René Dubos argumentou, a vis medicatrix naturae encontrou nova força, não na medicina, onde os poderes do médico gradualmente substituíram os da natureza, mas nas artes curativas da arquitetura da paisagem, da ecologia e da conservação. ${ }^{52}$ Aqui, eu argumentei, nas profissões ambientais emergentes, que objetivavam combater o mal-estar geral da civilização que vencia a nação, a doutrina hipocrática encontrou nova morada. Considere, por exemplo, um lugar onde a ansiedade urbana sobre a saúde no final do século XIX ajudou a destilar um tônico mais purificado de natureza: o desenho ambiental [environmental design].

Em 1890, Charles Eliot, filho do reitor de Harvard, Charles W. Eliot, e aprendiz do arquiteto de paisagem Frederick Law Olmsted, publicou em Garden and Forest [Jardim e floresta] um plano para o estabelecimento de uma organização de preservação e conservação que abrangesse o estado em Massachusetts. Aprovada pela legislatura do Estado apenas quinze meses após 
a primeira aparição do artigo de Eliot, os Conselhos Administradores das Reservas Públicas, um modelo para o Conselho Nacional Britânico, foi uma associação incorporada de cidadãos com direito a adquirir e manter, livres de impostos, pequenas porções de terra que representavam "fragmentos sobreviventes característicos da vida selvagem primitiva da Nova Inglaterra" ${ }^{53}$ Assim como alguns "homens e mulheres generosos compram e doam obras de arte aos museus", também, Eliot argumentava, eles deveriam ser encorajados a doar para "o uso e apreciação do público trabalhos da natureza finamente e fortemente caracterizados". Como arquiteto chefe da Comissão do Parque Metropolitano de Boston, Eliot era um líder no planejamento da paisagem regional, e a saúde figurava centralmente no seu conceito de design. Embora ele reconhecesse que "o avanço futuro da civilização" dependia "principalmente das influências pelas quais as mentes dos homens e seu caráter eram afetados pela vida na cidade grande," Eliot acreditava que "grandes perigos" os espreitavam. A "doença" era "mais prevalente na cidade do que fora dela". Vício, crime e as "favelas muito pobres das cidades" levavam a uma "raça degradada". Onde, perguntava Eliot sugestivamente, um "antídoto para a batalha venenosa e o excitamento da vida na cidade" pode ser encontrado? No "ar puro e espaços abertos" da natureza. ${ }^{54}$ Apenas uma década mais tarde, John Muir lançou um olhar esperançoso sobre as "milhares de pessoas cansadas, com nervos abalados, e super-civilizadas" que se aventuravam sobre as montanhas "para se livrar da ferrugem e da doença" e descobrir "que parques e reservas nas montanhas são úteis não apenas como fontes de madeira e rios para irrigação, mas como fontes de vida". ${ }^{55}$ Ainda, o que poderia ser feito por aqueles que não tinha "um bem valioso para gastar", ou meios para "deixar a cidade" e passar o verão na costa ou em resorts nas montanhas? Adiar a construção de parques nos limites das cidades era, de acordo com Eliot, "uma economia muito pobre de vida humana... e dinheiro". ${ }^{56}$ Assim como muitos dos reformistas do final do século XIX, daqueles envolvidos nos movimentos por parques na cidade até o Fundo pelo Ar Fresco [Fresh Fund Air], Eliot acreditava que trazer a natureza para os limites da cidade criaria grande benefício para a saúde física e moral daqueles que viviam onde o concreto, o lixo e a miséria pareciam proliferar. A natureza, do seu ponto de vista, também ajudaria a melhorar as condições em que o desespero e o descontentamento que ameaçavam a saúde da nação pareciam se criar.

Embora estejamos aptos a interpretar as observações de Eliot figurativamente, deveríamos estar atentos ao impulso de mapear argumentos 
racionais para os benefícios estéticos e psicológicos da natureza, carente da sua base material, em corpos e paisagens do passado. O benefício terapêutico da natureza que Eliot abraçou e construiu na paisagem urbana não era apenas uma ideia etérea. Assim como as meditações sobre a natureza de Ralph Waldo Emerson, Henry David Thoreau e outros transcendentalistas da New England que Eliot tinha absorvido, ela tinha uma substância terrena, incorporada na experiência de doença na infância e na família. Sabemos ainda muito pouco sobre as formas como a doença obrigou os escritores do século XIX a procurar alívio na natureza, mas o padrão é surpreendente. A tuberculose, conhecida por seus sofredores como tísica, responsável por 20 por cento das mortes na América pré guerra civil. Era a principal causa da morte em Concord. Emerson veio de uma família de tísicos; assim como Thoreau, que morreu da doença quando tinha 44 anos. Nove anos antes de sua morte, Thoreau escreveu que a "natureza não é senão outro nome para saúde", e sua permanência no Lago Minnetonka em Minnesota, entre outros lugares, foi uma jornada em busca da "cura pela vida natural". ${ }^{57}$ Enquanto criança, Charles Eliot parecia ter herdado a mesma constituição frágil e melancólica de sua mãe, uma característica que sinaliza a doença a que sua mãe muito provavelmente sucumbiu quando Charles não tinha mais do que dez anos. Seu pai, procurando assegurar que o destino familiar não recaísse sobre seu filho, procurou uma "vida ativa" para a criança e organizou verões em acampamentos, velejando e caminhando na Iha de Mount Desert em Maine ou viagens mais distantes ao norte de Quebec. Como essas experiências com a tuberculose deram forma às atitudes do século XIX em relação à natureza e a transformação das paisagens, tais como as montanhas Adirondack, onde milhares de sofredores foram em busca de alívio, questiona o seu autor. Uma olhada rápida sugere que a doença era parte integral da experiência da paisagem no século XIX assim como o sublime romântico. Eliot conhecia os poderes curativos da natureza por experiência própria, e procurava trazer sua influência para a cidade, onde ela poderia trabalhar seus milagres sobre as "forças da escuridão, as forças que arrastam o homem, as forças que empurram os homens para os braços da ignorância, do pecado e da morte." ${ }_{58}$

Ainda assim, não era apenas na cidade onde a natureza como antídoto da civilização precisava ser restaurada e preservada. A saúde poderia ser uma razão tão convincente para conservação no final do século XIX e início do século XX quanto os argumentos mais familiares aos historiadores ambientais focados em bacias hidrográficas evidentes, na extração sustentável de madeira e nas terras de pastagem reconstituídas. Consideremos, por 
exemplo, a resposta da Era Dourada à aparição de uma nova doença da civilização nas terras Americanas: a febre do feno. Largamente considerada um sintoma do rápido progresso, da complacência moral e da degeneração física da vida moderna civilizada, a febre do feno tornou-se o orgulho da classe de lazer americana e a base da economia do turismo que começou a florescer nos anos 1880. No meio de agosto de cada ano, milhares de ricos sofredores da febre do feno fugiam do calor, da sujeira e da poeira das cidades para relaxar em resorts de luxo da febre do feno nas áreas selvagens cultivadas das White Mountains em New Hampshire, nas Adirondacks na parte alta do Estado de Nova Iorque e à beira dos Great Lakes do Meio Oeste. Procurando alívio dos olhos lacrimejantes, nariz escorrendo, ataques de espirro e ataques de asma que se desenvolviam com regularidade sazonal, esses perseguidores da saúde, que incluíam homens da política, tais como Daniel Webster, e figuras literárias, como Helen Hunt Jackson e Grace Greenwood, tiveram um importante papel na transformação local e regional da paisagem norte-americana em nome da saúde. ${ }^{59}$

Nas White Mountains, por exemplo, os turistas da febre do feno eram estranhos à comunidade local, mas sua riqueza, mecenato e doença combinados os tornavam uma força poderosa no desenvolvimento regional e no uso da terra. Eles eram não apenas a razão primeira de a estação de turistas na região se prolongar até o início do outono, como também tiveram um papel importante no estabelecimento do parque estadual Franconia Notch e da Floresta Nacional de White Mountain. Quando o Clube de Montanha Appalachian, a Sociedade para Preservação das Florestas de New Hampshire, e a Nova Comissão Florestal de New Hampshire lançaram uma campanha em 1890 para estabelecer uma reserva florestal federal em White Mountains, os pacientes da febre do feno estavam entre seus mais ativos apoiadores. As florestas densas e altas montanhas da região criavam uma barreira aos ventos do sul, que também pareciam agravar os sintomas quando apareciam. Muitos pacientes da febre do feno acreditavam que a "passagem dos ventos do sul pela floresta roubava-lhes seus elementos nocivos". As "florestas", conforme observado por um membro da Associação Americana da Febre do Feno, "tinham uma relação importante com a doença e não deveriam ser destruídas". ${ }^{60}$ Esse sentimento estava de acordo com a opinião médica popular nos anos 1880, quando médicos e outros atribuíam valor terapêutico às florestas coníferas, particularmente no tratamento da malária e suas complicações.$^{61}$ Essa visão ajudou a influenciar as legislaturas estaduais. Em seu relatório à nova legislatura de New Hampshire em 1891, a Comissão Florestal 
listou as "qualidades que dão vida e restauram a saúde" da região de White Mountain como uma das quatro razões primárias para proteger e preservar as florestas estaduais. ${ }^{62}$ John D. Quackenbos, um ativista da Sociedade de Preservação das Florestas de New Hampshire, da mesma forma elevou os benefícios dos "grandes ozônios perfumados e aromas balsâmicos" das florestas perenes de New Hampshire para ajudar a angariar suporte para propriedade pública das florestas de White Mountain.

Embora os historiadores ambientais tenham sido rápidos em rejeitar a afirmação de Quackenbos como "bobagem médica" ela estava baseada na experiência empírica e no conhecimento científico da época. ${ }^{63} \mathrm{O}$ exemplo mostra mais uma vez os perigos que surgem quando os historiadores ambientais não consideram o conhecimento científico como um produto histórico do tempo e do lugar. A rejeição desse conhecimento por não estar de acordo com a opinião médica contemporânea rouba desse conhecimento a agência real que ele teve na criação das paisagens históricas. As propriedades da terebintina das florestas coníferas da New England e os benefícios perceptíveis à saúde podem evadir os sentidos e a sabedoria dos sofredores da alergia contemporânea e dos médicos, mas eles não foram menos reais aos sofredores da febre do feno do século XIX, que agiram mediante suas experiências sensoriais de formas que objetivavam preservar as qualidades terapêuticas da região.

Construída dentro das paisagens dos parques da cidade e das reservas florestais do leste, a saúde também era uma característica proeminente da fronteira oeste. Então, não deveria nos surpreender que as vozes daqueles que procuravam a saúde e aqueles que expressavam preocupação com a exploração dos recursos naturais fossem frequentemente as mesmas. Helen Hunt Jackson fazia uma crítica aberta aos efeitos para a saúde do consumo desenfreado de recursos em nome da expansão industrial e do progresso. Sua primeira obra publicada que ganhou o reconhecimento e a admiração do principal poeta transcendentalista americano, Ralph Waldo Emerson, foi uma ode à cidade de Bethelem, em New Hampshire. Lá Jackson primeiro encontrou refúgio da febre do feno: lá as energias nervosas da cidade davam lugar a uma atmosfera relaxante da natureza primitiva. Ao final dos anos 1860, entretanto, Jackson escreveu em "protesto contra a propagação da civilização". Guiados pelo todo poderoso dólar, proprietários de hotéis tinham transformado seu pequeno vilarejo em uma economia de turismo próspera que ameaçava corromper a região e manchar seus benefícios terapêuticos. 0 bálsamo curativo da natureza acenava para Jackson no oeste. Como muitos 
que buscavam a saúde, ela encontrou alívio em uma nova terra prometida do Colorado, firmando residência permanente lá em 1874. Mas como Jackson trocou sua vida em New England pela vida de uma mulher do oeste, ela também via com ambivalência o rápido desenvolvimento da região que acontecia diante dos seus olhos. ${ }^{64}$

A chegada de pessoas que buscavam saúde, exploradores, empreendedores comerciais e investidores ao território do Colorado foi parcialmente promovida pelos escritos populares de Jackson e os interesses na estrada de ferro do seu esposo, William Palmer Jackson, mas com mais ênfase pela beleza natural, saúde e riquezas minerais. Para muitos, uma pessoa com asma, tuberculose ou febre do feno no século XIX que vinha ao Colorado buscando alívio, Deus tinha aparentemente criado através dos contornos particulares do solo, da vegetação e da altitude um lugar onde eles poderiam "respirar Seu ar com conforto e facilidade". ${ }^{65}$ Ainda assim, na procura por progresso material, o povo do Colorado ignorava às suas próprias custas o tesouro natural mais valioso adornado pela providência: a saúde. A fumaça que se espalhava das regiões de mineração das Rockies - como aquela de Black Hawk, a oeste de Denver, onde dezessete fornalhas do Serviço de Fundição de Boston e Colorado reduziam seis toneladas de metal diariamente - ofereciam um sinal de prosperidade financeira aos defensores do desenvolvimento, mas para aqueles que buscavam saúde como Jackson, a "fumaça amarela sufocante" que contrastava violentamente com o "ar fresco, seco e protetor da floresta" servia de lembrete de onde o progresso poderia os levar. ${ }^{66}$ As encostas rasgadas pela extração da madeira e os lagos das montanhas sujos já eram uma visão comum quanto Jackson se estabeleceu no Colorado nos anos 1870. No início dos anos de 1900, apenas 20\% das florestas originais do Colorado ainda existiam. "67 "Sejam quais forem os ganhos em sucesso material", Jackson escreveu sobre uma pequena cidade que apostava seu futuro na mineração, "ela terá perdido algo quando o apito da estrada de ferro e a confusão barulhenta das multidões tiverem espantado o antílope e o veado, que agora vem até o rio saciar sua sede." ${ }^{68}$ Viajando através das ravinas sujas, minas e "amontoados de casas" do distrito da mineração de Central City e Georgetown, Hunt previa um futuro em que as "rodas dos moinhos estarão paradas, as minas estarão vazias, e os peregrinos procurando as alturas... não por que elas oferecem prata e ouro, mas porque são graciosas e bonitas e dão saúde". ${ }^{69}$ Quando a economia do Colorado se desequilibrou depois da queda do preço da prata no início dos anos 1890, Jackson achou importante relembrar seus concidadãos uma vez mais de que "o contágio da pressa em 
enriquecer é tão mortal quanto o contágio da doença". ${ }^{70}$ Muito consciente do impacto social e ambiental da mineração irresponsável e a precariedade do futuro do Colorado, Jackson viu o destino do estado não na super exploração dos seus recursos minerais, mas na preservação e proteção de seu clima, onde "a asma, as doenças da garganta e os estágios iniciais da tuberculose" eram, "quase sem exceção, curados pelo ar seco e rarefeito". ${ }^{71}$

Jackson não foi a única escritora proeminente no século XIX cujas viagens ao oeste em busca de saúde inspiraram uma ética conservacionista contínua. Os primeiros anos que Theodore Roosevelt gastou em busca de viagens de saúde para os Alpes, Adirondacks, White Mountains e Badlands, onde se acreditava que uma mudança de ares ofereceria alívio dos sintomas de asma crônica - foram também fundamentais na sua crescente apreciação da vida natural. Mas ainda precisamos investigar completamente como tais experiências de doenças se traduziram em ação política mobilizada em torno da conservação das florestas, campos e rios. ${ }^{72}$

Enquanto as relações entre saúde, sentimento público e ação legislativa no movimento conservacionista progressivo merecem uma atenção mais séria, uma coisa é certa. No final do século XIX, uma grande classe de indivíduos urbanos, ricos e refinados descobriram em sua própria constituição uma predisposição nervosa aos males da civilização. ${ }^{73}$ Sua cura repousava na pureza da natureza. Se a poluição, conforme sugere Mary Douglas, é a matéria fora de lugar, então a América do final do século XIX foi um período em que a busca por pureza provou-se ainda mais atraente porque esse foi um período em que os deslocamentos floresceram. ${ }^{74} \mathrm{O}$ grande afluxo de imigrantes europeus do sul e leste, a mudança de uma população rural para uma população urbana, e a movimentação rápida de capital, produtos e pessoas pela estrada de ferro através de regiões antigamente isoladas, resultou em novas ansiedades e doenças. Catarses de várias formas eram administradas pela classe de profissionais brancos de classe média e alta para limpar a paisagem dos corpos estranhos e restaurar os poderes curativos da natureza. ${ }^{75} \mathrm{~A}$ remoção dos americanos nativos dos parques nacionais foi uma depuração na purificação da natureza que é familiar aos historiadores ambientais. ${ }^{76}$ Aqui eu gostaria de sugerir outra que ainda não foi suficientemente explorada.

Os historiadores ambientais já sabem há algum tempo que muitos dos líderes do movimento de conservação progressivo - Theodore Roosevelt, Madison Grant, Henry Fairfield Osborn e Gifford Pinchot, para citar apenas alguns - também foram alguns dos mais fiéis apoiadores da eugenia. ${ }^{77} \mathrm{En}$ quanto aquela ligação tem sido usada com orgulho pelos higienistas da raça 
que publicaram em revistas de extrema direita tais como Mankind Quarterly, que tem valorizado a consciência progressiva e a previsão de indivíduos como Madison Grant, o fundador da Liga Save the Redwoods e autor do tratado nativista, The Passing of the Great Race [A passagem da grande raça], a conexão entre conservação e eugenia é algo que poucos historiadores ambientais americanos parecem desejosos de confrontar. ${ }^{78}$ Mas a recente, altamente contestada e difundida eleição dos candidatos anti-imigração para o conselho diretor do Sierra Club deveria nos lembrar de quão longas e profundas são as correntes entrelaçadas da conservação e dos sentimentos nativistas no fluxo americano. 0 medo de contágio, de mistura, de poluição é uma ponte comum que abrange essas correntes interligadas. E é através de uma história de paisagem e da doença, sugiro, que os historiadores ambientais americanos podem começar a escrever o que Karl Jacoby muito habilmente descreveu como a "história escondida" da conservação, uma história a partir de baixo que traria questões de justiça social mais à tona na história ambiental americana. ${ }^{79}$

Argumentos a favor da conservação do germoplasma da nação foram sempre vistos como uma parte de uma plataforma legislativa mais abrangente para um manejo mais efetivo dos recursos da nação. No segundo Congresso Nacional Sobre Conservação, evento anual realizado entre 1909 e 1913 para promover a consciência pública da necessidade de conservação, a Sr. . Matthew T. Scott, presidente geral das Filhas da Revolução Americana, capturou as formas em que a conservação do patrimônio natural e racial americano foram considerados igualmente importantes na preservação da saúde da nação. "Nós, as mães dessa geração - ancestrais das futuras gerações, temos o direito de insistir sobre a conservação não apenas do solo, da floresta, dos pássaros, dos minerais, dos peixes, dos cursos d'água no melhor interesse de nossas futuras donas de casa," Scott proclamou, "mas também sobre a conservação da supremacia da raça caucasiana em nossa terra". ${ }^{80}$ Tais observações não eram simplesmente nobre retórica política. Elas tinham uma base concreta nas disputas contestadas e às vezes violentas sobre o uso da terra que surgiram na virada do século XX. Enquanto a elite rica urbana americana procurava refúgio na natureza contra os males da civilização, ela frequentemente encontrava corpos impuros, pessoas a quem consideravam como poluentes das suas tão amadas paisagens por viverem na "natureza da forma errada". ${ }^{81}$

As montanhas Ramapo de New Jersey, uma área que Kevin Dann explora no mapeamento do que ele habilmente chama "a geografia dos 
debilitados mentalmente", era um tal lugar onde o esforço para conservação dos recursos biológicos da América - tanto humanos quanto naturais estavam amarrados a competições sobre o uso da terra. Terra natal de um povo a quem foi dado o nome depreciativo de Jackson-Whites em a sua herança de raça mista e estilo de vida com subsistência/economia misto, a região também tinha se tornado a moradia sazonal de alguns dos mais importantes capitães da indústria nacional, tais como Edward II Harriman, um magnata da estrada de ferro e aliado político de Theodore Roosevelt, cuja propriedade de trinta milhas quadradas oferecia um santuário para a "grande colméia de humanidade se arrastando através de um mundo artificial, cheio demais para a saúde da mente e do corpo" em Nova York. Em 1910, um ano após a morte de seu marido, Mary Harriman doou $\$ 10.000$ para o estabelecimento do Escritório de Registro de Eugenia, acreditando nos objetivos de seu diretor, Charles Benedict Davenport, de "desenvolver... a regeneração física e social de nosso amado país". ${ }^{82}$ Entre a elite, alguns sentiam que os Jackson-Whites e outras pessoas da área rural que ocupavam os edifícios vazios, caçavam e roubavam os recursos da floresta adjacente e das paisagens de regeneração as quais a classe patrícia americana ocupavam, manchavam a pureza e virtude da natureza e dessa forma ameaçavam a saúde tanto dos indivíduos quanto da nação. Lixo branco, ratos do rio, ou ervas daninhas humanas, eles precisavam ser arrancados da paisagem. ${ }^{83}$ Muitas dessas famílias rurais os infames "Jukes" de Catskills, por exemplo - tornaram-se o alvo e sujeito das pesquisas do campo da eugenia. Classificados como degenerados, eles eram fisicamente removidos da terra e colocados em instituições do Estado onde eram instruídos a ter relações mais "produtivas" e saudáveis com a natureza ${ }^{84}$ Mas o bem estar e a saúde de quem estavam sendo preservados? Raça e classe sempre figuraram notavelmente na história do meio ambiente e saúde na América. Isso não é menos verdade na designação de áreas selvagens do que na localização dos aterros de lixo tóxico nos Estados Unidos. ${ }^{85}$

\section{Conclusão}

Nossas viagens em busca da saúde nos levaram a uma viagem extensiva, do gerenciamento da vida selvagem no Wisconsin à administração colonial no império britânico, da ecologia da doença à ecologia do conhecimento, da fronteira oeste à paisagem de regeneração nos parques das cidades e refúgios em áreas selvagens. Nós retornamos ao nosso ponto de partida: Leopold e Um almanaque de Sand County. Mas talvez esse não seja exatamen- 
te o mesmo lugar onde começamos. Ao final da jornada, talvez possamos concordar que é perturbador que esse texto clássico da história ambiental seja tão frequentemente ensinado de formas que reforçam categorias que herdamos das primeiras décadas do século XX. Nós esquecemos ou falhamos em reconhecer que Leopold tanto ressuscitou e resgatou a ideia da saúde da terra em um período quando a cura se baseava não tanto na pureza que implicava uma separação dos humanos da natureza - como tinha sido o caso da geração anterior - como na interpretação da economia animal, política e natural. Logo após a morte de Leopold, Frank Fraser Darling, Clarence Glacken, Marston Bates, Carl Sauer, Lewis Mumford e outros fariam eco à sua visão no simpósio de Wenner-Gren sobre o "Papel do homem na mudança da face da terra", em 1955. A constelação de antropólogos, ecologistas, economistas, historiadores, geólogos, geógrafos e planejadores que se reuniram em conferência - uma lista que era um 'quem-é-quem' de pessoas que tiveram um impacto sobre a primeira geração de historiadores ambientais americanos - veio a reconhecer a ecologia animal, das plantas e humana como parte da mesma paisagem e campo de estudos. ${ }^{86}$

Enquanto os historiadores ambientais tenham talvez banido a saúde porque ela evoca cobranças do antropocentrismo, a virtude da saúde nos anos entreguerras foi precisamente de ela ser transversal à divisão homem/ natureza. Não devemos deixar que as categorias de nossos atores históricos nos ceguem e nos levem a pensar que o tema da saúde está limitado à história ambiental urbana ao passo que, de uma certa forma, tenha menos relevância à história das paisagens rurais. Ar e água, micróbios e pólen, químicos tóxicos e radiação se movem para dentro e para fora das paisagens urbana e rural, através dos corpos, tanto humanos quanto não humanos. Como tal questão se forma, cria agência nos corpos e paisagens, se torna um bem no consumo da saúde, ou se torna um perigo e risco, esses são todos tópicos que merecem um estudo mais cuidadoso do que eu possa ter sido capaz de realizar aqui. Minha suspeita é de que quando a saúde estiver mais completamente integrada à paisagem da história ambiental americana, ela produzirá naturezas muito mais texturizadas, complexas e diversas das que temos atribuído ao passado.

\section{Notas}

Meus agradecimentos a Adam Rome por seu encorajamento, feedback e paciência, e a Warick Anderson, Eric MacDonald, Linda Nash e Paul Sutter por seus comentários muito úteis. O Colóquio sobre História Ambiental na 
Universidade de Wisconsin-Madison provou-se um ambiente inacreditavelmente favorável em auxiliar a nutrir as ideias desse artigo, e meus agradecimentos aos esforços de organização de Bill Cronon, Nancy Langston, e Art McEvoy em fazer com que acontecesse. Esse trabalho teve o suporte das bolsas para pesquisa do American Council of Learned Societies e do Centro Nacional de Humanidades e da Fundação Nacional de Ciência, bolsa SES-0196204.

1. Ver, por exemplo, J. Baird Callicott, In Defense of the Land Ethic: Essays in Environmental Philosophy (Albany: State University Press of New York, 1989)

2. Há sinais de que essa tendência esteja mudando na história ambiental americana além dos limites do ambiente urbano, onde o tema saúde tem sido mais visível. Ver, por exemplo, o ensaio em Gregg Witman, Michele Murphy e Christopher Sellers, org., Landscapes of Exposure: Knowledge and Illness in Modern Environments (Chicago: University of Chicago Press, 2004), Conevery Bolton Valençius, The Health of the Country: How American Settlers Understood Themselves and Their Land (New York: Basic Books, 2002), Linda Nash, "Finishing Nature: Harmonizing Bodies and Environments in Late NIneteenth Century California", Environmental History (2003), 25-52, Linda Nash "Transforming the Central Valley: Body, Identity and Environment in California, 1850-1870" (tese de doutorado, Universidade de Washington, 2000). Os encontros da Sociedade Americana de História Ambiental também tiveram algumas sessões devotadas a tópicos de saúde.

3. Esta é a tese de Samuel Hay, Beauty, Health, and Permanent Environmental Politics in the United States, 1955-1985 (Cambridge: Cambridge University Press, 1985) que continuam válidas.

4. Para um exemplo dessa literatura, ver Robert Gottlieb, Forcing the Spring: The transformation of the Environmental Movement (Washington, DC: Island Press. 1993); Andrew Hurley, Environmental Inequalities: Class, Race and Industrial Pollution in Gary, Indiana. 1945-1980 (Chapel Hill: University of North Carolina Press. 1995); Martin Melosi, The Sanitary City: Urban Infrastructure in America from Colonial Times to the Present (Baltimore: Johns Hopkins University Press. 2000); Arthur McEvov, "Working Environments: An Ecological Approach to Industrial Health History," Technology and Culture (suppl.) (1995): 145-73, Gerald Markowitz e David Rosner, Deceit and Denial: The Deadly Politics of Industrial Pollution (Berkeley and Los Angeles: University of California Press, 2002); David Rosner e Gerald Markowitz, Deadly Dust: Silicosis and the Politics of Occupational 
Disease in Twentieth-Century America; Christopher Sellers, Hazards of the Job: From Industrial Disease to Environmental Health Science (Chapel Hill: University of North Carolina Press, 1997); David Stradling, Smoskestacks and Progressiveness: Environmentalists, Engineers, and Air Quality in America, 1881-1951 (Baltimore; John Hopkins University Press, 1999); e Joel Tarr, The Search for the Ultimate Sink: Urban Pollution in Historical Perspective (Akron, Ohio: University of Akron Press, 1996);

5. O foco desse ensaio está grandemente centrado nas intersecções da ecologia, gerenciamento de recursos naturais e saúde nos Estados Unidos antes da Segunda Guerra Mundial. Eu explicitamente escolhi não incluir os desenvolvimentos após Segunda Guerra Mundial, nem tampouco incluir áreas como saúde ocupacional ou saneamento, onde as conexões com as preocupações com recursos naturais são mais tangenciais.

6. Ver Christopher Lawrence e George Weisz, orgs., Greater Than the Parts: Holism in Biomedicine, 1920-1950 (New York: Oxford University Press, 1998).

7. Walter B. Cannon. The Wisdom of the Body (New York: W. W. Norton, 1932). De Georges Canguilhem The Normal and the Pathological, trad. de Carloyn R. Fawcett, com uma introdução de Michel Foucault (New York: Zone Books, 1991) ainda se destaca como o mais magistral tratamento das mudanças nas relações históricas entre o normal e o patológico.

8. Citado em Stephen J. Cross e William R. Albury, "Walter B. Cannon, L. J. Henderson, and the Organic Analogy" Osiris, $2^{\text {nd }}$ ser., (1987): 171 . Ver também Alan Young, "Walter Cannon and the Psychophysiology of Fear", em Greater than the Facts, ed. Lawrence e Weisz, 234-56.

9. Cannon, Wisdom of the Body, 294-300.

10. Ibidem, 297.

11. Citado em Meine, Aldo Leopold, 350.

12. Aldo Leopold, A Sandy County Almanac with Essays on Conservation from Round River (New York: Ballantine Books, 1970), p. 274. Sobre a história da Economia e Regulamentação na ciência da vida no século XIX, ver Georges Canguilhem, Ideology and Rationality in the History of Life Sciences, trad. Arthur Goldhammer (Cambridge: MIT Press, 1988) 81-102. Ver também Donald Worster, Nature's Economy: A History of Ecological Ideas, 2a. Edição (Cambridge: Cambridge University Press, 1994).

13. Sobre a África do Sul, ver Peder Anker, Imperial Ecology: Environmental Order in the British Empire, 1895-1945. (Cambridge: Harvard University 
Press, 2001); sobre a Alemanha, ver Paul Weindling, Health, Race and German Politics between National Unification and Nazism 1870-1945 (Cambridge: Cambridge University Press, 1989); sobre os Estados Unidos, ver Gregg Mitman, The State of Nature: Ecology, Community and American Social Thought, 1900-1950 (Chicago: University of Chicago Press, 1992). Para uma visão mais extensiva da autoridade moral da natureza em diferentes tempos e lugares, ver Lorraine Daston e Fernando Vidal, (orgs.) The Moral Authority of Nature (Chicago: University of Chicago Press, 2004).

14. Cannon, Wisdom of the Body, p. 21.

15. Arthur Castiglioni, "Neo-Hipocratic Tendency of Contemporary Medical Thought," Medical Life (1934): 128-29.

16. René Dubos, Mirage of Health: Utopias, Progress and Biological Change (New York: Harper Bros., 1959), 117.

17. Citado em Meine, Aldo Leopold, 350-51.

18. Leopold, A Sandy County Almanac, p. 274. Ver também, Aldo Leopold, For the Health of the Land, ed. J. Baird Callicott e Eric T. Freyfogle (Washington, D. C.: Island Press, 1999), 218-26.

19. Richard Grove, Green Imperialism: Colonial Expansion, Tropical Island Edens, and the Origins of Environmentalism, 1600-1860 (Cambridge: Cambridge University Press, 1995). Ver também John M. Mackenzie, "Empire and the Ecological Apocalypse: The Historiography of the Imperial Environment", em Ecology and Empire: Environmental History of Settlers Society, ed. Tom Griffiths e Libby Robin (Seattle: University of Washington Press, 1997), 215-28.

20. Aldo Leopold, "The Land Health Concept in Conservation", em For the Health of the Land, ed. Callicott e Freyfogle, p. 222. Sobre o uso que Leopold faz do termo "irruption" (irrupção) ver Fladder, Thinking Like a Mountain, 177-80.

21. Sobre economia política e produção de espaço e lugar, ver William Cronon, Nature's Metropolis: Chicago and the Great West (New York: W. W. Norton, 1992); Mike Davis, Late Victorian Holocausts: El Niño Famines and the Making of the Third World (London: Verso, 2001); Henri Lefebvre, The Production of Space (New York: Oxford University Press, 1991); David Harvey, The Condition of Post-Modernity (Cambridge: Blackwell, 1990); David Harvey, Justice, Nature and the Geography of Difference (Cambridge: 
Blackwell, 1996); e David Harvey, Spaces of Capital: Towards a Critical Geography (New York: Rutledge, 2001).

22. Ver Anker, Imperial Ecology, Eugene Cittadino, Nature as the Laboratory: Darwinian Plant Ecology in the German Empire, 1880-1900 (New York: Cambridge University Press, 1990); e Griffiths e Robin, orgs. Ecology and Empire.

23. Curt Meine atribui à Conferência de Matamek e a reunião de Elton como influência decisiva no amadurecimento da abordagem ecológica de Leopold à conservação. Ver Meine, Aldo Leopold, 283-84. A adoção do termo "irrupção" por Leopold no início dos anos 1940 para descrever os ciclos da população de cervos deve muito ao trabalho de Elton sobre os ciclos de população animal e as doenças zoonóticas.

24. Sabemos muito pouco sobre o desenvolvimento e a recepção do trabalho de Elton na história da ecologia. Para um início importante, ver Anker, Imperial Ecology (Ecologia Imperial), e David L. Cox, "Charles Elton and the Emergence of Modern Ecology" (tese de doutorado, Washington University, 1979). Para uma história ilustrativa, ver Peter Crowcroft, Elton's Ecologists:A History of the Bureau of Animal Population (Chicago: University of Chicago Press, 1991).

25. Charles Elton, Animal Ecology, 1927; reimpressão, (Chicago: University of Chicago Press, 2001), p. 110.

26. Julian Husley, Introduction to Elton, Animal Ecology, xv.

27. Charles Elton, Voles, Mice and Lemmings: Problems in Population Dynamics (Oxford: Clarendon Press, 1941), 482.

28. Charles S. Elton, The Ecology of Invasions by Animals and Plants (London: Methuen, 1958) 18-19.

29. Huxley, Introdução, xiv.

30. Helen Tilley, "Ecologies of Complexity: Tropical Environments, African Trypanosomiasis, and the Science of Disease Control Strategies in British Colonial Africa, 1900-1940," Osiris (2004): 21-38, citação em 35.

31. Huxley, Introdução, xiv.

32. John F. V. Phillips, “The Application of Ecological Research Methods to Tsetse (Glossina SPP) Problem in Tanganyika Territory: A Preliminary Account." Ecology (1930).

33. F. M. Burnet, Biological Aspects of Infectious Disease (Cambridge: Cambridge 
University Press, 1940), 4. Ver também Dubos, Mirage of Health; René Dubos, Man Adapting (New Haven: Yale University Press, 1965). Eu devo as expressões "teatro ecológico" e "peça evolucionária” a obra de George Evelyn Hutchinson, The Ecological Theater and the Evolutionary Play (New Haven: Yale University Press, 1965). É surpreendente, dada a influência de Dubos no movimento ambiental, que tão pouco tenha sido escrito sobre ele por historiadores ambientais.

34. Sobre dois artigos importantes que iniciaram a explorar a história da ecologia da doença e oferecer links sugestivos a esse trabalho mais recente sobre a história ambiental, ver Warwick Anderson, "Natural Histories of Infectious Diseases: Ecological Vision in Twentieth-Century Biomedical Science," Osiris (2004):39-61; e Tilley, "Ecologies of Complexity".

35. William H. McNeill, Plagues and Peoples (New York: Doubleday, 1977); Alfred Crosby, The Columbian Exchange: Biological and Cultural Consequences of 1942 (Westport, Conn.: Grenwood, 1972); Alfred Crosby, Ecological Imperialism: The Biological Expansion of Europe, 900-1900 (Cambridge: Cambridge University Press, 1986); Jared Diamond, Guns, Germs and Steel: The Fates of Human Societies (New York: W.W. Norton, 1997). Nesse best-seller, The Hot Zone (New York: Random House, 1994), 288, Richard Preston vai mais longe ao sugerir que a emergência da AIDS, ebola e outras doenças emergentes são a forma da natureza equilibrar-se contra a "infecção pelo parasita humano". Outros trabalhos mais remotos, tais como de William Cronon Changes in the Land: Indians, Colonists and the Ecology of New England (New York: Hill \& Wang, 1983); e Land Use, Environment and Social Change: The Shaping of the Island County, Washington (Seattle: University of Washington Press, 1980), concedem à cultura um papel mais mediador em como a doença adquiriu agência na mudança da paisagem.

36. Para uma referência a esse debate, ver David Demeritt, "Ecology, Objectivity and Critique in Writings on Nature and Human Societies," Journal of Historical Geography (1994): 22-37, e William Cronon, "Cutting Loose or Running Aground", Journal of Historical Geography (1994): 3843. Para uma tentativa mais recente de abrir esse diálogo, ver Gregg Mitman, Michele Murphy e Christophen Gellers, "Introduction. A cloud over history," (2004):1-20.

37. Isso se baseia em duas décadas de estudos sobre ciência e tecnologia. Para um exemplo eclético, ver Lorraine Daston, "Historical Epistemology", 
em Questions of Evidence: Proof, Practice and Persuasion across the, org. James Chandler, Arnold Davidson, e Harold Harootunian (Chicago: University of Chicago Press, 1994); Donna Haraway, Modest Witness@ Second Millennium. Female Man Meets Onco Mouse: Feminism and Technoscience (New York: Routledge: 1997);Bruno Latour, Science in Action: How to Follow Engineers and Scientists Through Society (Cambridge: Harvard University Press, 1987); Bruno Latour, Pandora's Hope: Essays on the Reality of Science Studies (Cambridge: Harvard University Press, 1999); Andrew Pickering, The Mangle of Practice: Time, Agency and Science (Chicago: University of Chicago Press, 1995); and Simon Schaffer and Steven Shapin, Leviathan and the Air-Pump: Hobbes, Boyle and the Experimental Life (Princeton: Princeton University Press, 1985).

38. Anderson, "Natural Histories of Infectious Disease." p. 58.

39. Paul Sutter, "Reflections: What can US Environmental Historians Learn from Non-US environmental Historiography. Environmental History (2003): 109-29.

40. Sobre as Filipinas, ver Michael Adas, "Improving on the Civilization Mission? Assumptions of United States Exceptionalism in the Colonisation of the Philippines," Itinerário (1998): 44-66; Warwick Anderson, The Natures of Culture: Environment and Race in the Colonial Tropics," em Nature in the Global South: Environmental Projects in South and Southeast Asia, ed. Paul Greenough e Anna Lowenhaupt Tsing (Durham: Duke University Press), 29-46; e Warwick Anderson, "Immunities of Empire: Race, Disease and the New Tropical Medicine, 1900-1920, "Bulletin of the History of Medicine" (1996): 94-118. Tanto Adas quanto Anderson estão trabalhando em projetos de livros sobre as Filipinas. Sobre a indústria da Banana, ver Steve Marquardt, "Green Havoc": Panamá Disease, Environmental Change, and Labor Process in the Central American Banana Industry," American Historical Review (2001):49-80, e Steve Marquardt, "Pesticides, Parakeets, and Unions in the Costa Rican Banana Industry, 19381962, "Latin American Research Review (2002) 3-36. Um número de estudiosos iniciaram um trabalho sobre a história ambiental do Canal do Panamá. Ver Stephen Frenkel, "Geographical Representations of the 'Other": The Landscape of the Panama Canal Zone," Journal of Historical Geography (2002): 85-99; John Lindsay- Poland, Emperors in the Jungle. The Hidden History of the US in Panamá (Durham: Duke University Press, 2003); e o projeto de pesquisa atual de Paul Sutter "Pulling the Teeth of 
the Tropics: Environment, Disease, Race and the US Sanitary Program in Panama,"; Richard Tucker, Insatiable appetite: The United States and the Ecological Degradation of the Tropical World (Berkeley e Los Angeles: University of California Press, 2000) tem uma pequena seção sobre Firestone na Libéria. Esse é um assunto que eu espero abordar no meu próximo projeto, inicialmente intitulado “America's rubber empire: Science, Commerce and Disease in the Making of Firestone Plantations Company."

41. Timothy Mitchell, Rule of Experts: Egypt, Techno-Politics, Modernity (Berkeley e Los Angeles: University of California Press, 2002), 52. Mitchell se baseia na teoria ator-rede (ANT) nos estudos de ciências para falar de agências híbridas. Eu acredito que ANT oferece uma das abordagens mais úteis nos estudos de ciências para os historiadores ambientais para repensar como a natureza ganha voz nas narrativas históricas. Ver, por exemplo, Latour, Pandora's Hope; John Law e John Hassard, orgs., ActorNetwork Theory and After" (Oxford: Balckwell, 1999); e Michell Callon e John Law, "Agency and Hybrid Collectif." South Atlantic Quarterly (1995): 581-607.

42. Leopold, A Sand County Almanac, 269.

43. Valençius, Health of the Country.

44. G.E.R Lloyd, org., Hippocratic Writings (London: Penguin Books, 1978), 148.

45. Nash, "Finishing nature," 25-51, citação em 25.

46. Sobre o corpo como instrumento de medidas ambientais e um barômetro do lugar, ver Michael Dettelbach, "The Face of Nature: Precise Measurement, Mapping, and Sensibility in the Work of Alexander Von Humboldt", Est. Hist. e Filos. Biol. E Biomed. Ciências (1999): 473-504; Nash, "Finishing Nature" e Gregg Mitman, "Hay Fever Holiday: Health, Leisure, and Place in Gilded Age America”, Bulletin of the History of Medicine (2003): 600-635. Sobre Joseph Henry, ver James R. Fleming, Metereology in America, 18001870 (Baltimore: Johns Hopkins University Press, 1990).

47. Daniel Drake, A Systematic Treatise, Historical, Etiological, and Practical, on the Principal Diseases of the Interior Valley of North America (Cincinnati, Ohio: Winthrop B. Smith, 1850). Sobre geografia médica na América do século XIX, ver James H. Cassedy, Medicine and American Growth (Madison: University of Wisconsin Press, 1986), especialmente o capítulo 3: Valençius, Health of the Country, especialmente capítulo 4: Conevery Bolton Valençius, "Histories of Medical Geography,", em Medical Geography 
Perspective, org. Nicolas Rupke (London: Wellcome Trust Centre for the History of Medicine UCL, 2000), 3-20; e Gregg Mitman e Ronald Numbers, "From Miasma to Asthma: The Changing Fortunes of Medical Geography in America," History and Philosophy of the Life Sciences (2003): 391-412.

48. Alguns exemplos incluem Susan Jane Edwards, "Nature as Healer: Denver, Colorado's Social and Built Landscapes of Health, 1880-1930," (Tese de Doutorado, University of Colorado, 1994); Billy M. Jones, Health Seekers in the Southwest, 1817-1900 (Norman: University of Oklahoma Press, 1967); Nash, "Transforming the Central Valley"; Mitman, "Hay Fever Holiday"; Gregg Mitman "Geographies of Hope: Mining the Frontiers of Health in Denver and Beyond, 1870-1965," Osiris (2004): 93-111; Sheila Rothman, Living in the Shadow of Death: Tuberculosis and the Social Experience of Illness in American History (New York Basic Books, 1994); Valençius, Health of the Country; e Conevery Bolton Valençius, "Gender and the Economy of Health on the Santa Fe Trail," Osiris (2004): 79-92.

49. Sobre Central Valley Califórnia, ver Nash "Finishing Nature".

50. Denver e Rio Grande Railway Co., Health, Wealth and Pleasure in Colorado and New Mexico (Chicago, 1881), 15.

51. Para uma introdução sobre Saúde Pública e ambiente urbano, ver Melosi, Sanitary City.

52. Dubos, Mirage of Health, 127-28.

53. Citado em Charles W. Eliot, Charles Eliot: Landscape Architect (1902, reimpressão, Amherst: University of Massachusetts Press, 1999), 317. Meus agradecimentos a Eric MacDonald por chamar minha atenção para Eliot. Sobre Eliot e desenho ambiental, ver Keith N. Morgan, Introduction to Eliot, Charles Eliot, vii-l; Cynthia Zaitzevsky, Frederic Law Olmsted and the Boston Park System (Cambridge: Belknap Press, 1982).

54. Citado em Eliot, Charles Eliot, 318, 338-39, 341.

55. John Muir, Our National Parks (Boston: Houghton Mifflin, 1901), 1.

56. Citado em Eliot, Charles Eliot, 341-42.

57. Bradford Torrey, org., Writings of Henry David Thoreau (Boston: Houghton Mifflin Co., 1906), 11-395. Para uma reflexão provocante sobre o corpo de Thoreau e a historiografia da história ambiental, ver Christopher Sellers, "Thoreau's Body: Towards an Embodied Environmental History," Environmental History (1999): 486-514.

58. Citado em Eliot, Charles Eliot, 339. 
59. Para uma análise mais extensa, sobre o que o material deste parágrafo e do seguinte está baseado, ver Mitman "Hay Fever Holiday."

60. "Hay Fever" (Febre do Feno), White Mountain Echo, 13 Setembro 1879, 1.

61. Ver Kenneth Thompson, "Wilderness and Health in the Nineteenth Century," Journal of Historical Geography (1976): 145-61; e Kenneth Thompson, "Trees as a Theme in Medical Geography and Public Health," Bulletin of New York Academy of Medicine (1978): 517:31.

62. Report of the Forestry Commission of New Hampshire, January Session, 1891 (Manchester, N.H., 1891), 20.

63. Essa é a opinião de Richard W. Judd, Common Lands, Common People: The Origins of Conservation in Northern New England (Cambridge: Harvard University Press, 1997), 104-5, onde a citação de Quackenbos aparece.

64. Helen Hunt Jackson, "A Protest Against the Spread of Civilization" New York Evening Post, 29 Agosto 1867. Embora Rothman, em Vivendo à Sombra da Morte, ligue as jornadas de Jackson em busca de saúde ao consumo, os locais para onde Jackson viajou, a sazonalida, de suas viagens, e a referência à febre do feno por seu biógrafo do século dezenove sugerem que a febre do feno era uma razão tão convincente para suas viagens quanto o consumo. Para informação biográfica sobre Jackson, ver "Mrs. Helen Hunt Jackson," Century (Dezembro 1885): 251-59; Ruth Odell, Helen Hunt Jackson (New York: London, 1939); and Kate Phillips, Helen Hunt Jackson: A Literary Life (Berkely e Los Angeles: University of California Press, 2003).

65. Colorado and Asthma (Denver: Rock Mountain Steam News, 1874), p. 15.

66. Grace Greenwood, New Life in New Lands: Notes of Travel (New York: J. B. Ford \& Co., 1873), 75. Greenwood, um colega sofredor da febre do feno, ajudou a organizar a mudança de Jackson para o Oeste.

67. Ver Kathleen A. Brosnan, Uniting Mountain and Plain: Cities, Law and Environmental Change Along the Front Range (Albuquerque: University of New Mexico Press, 2002).

68. Helen Hunt Jackson, "Alamosa”, New York Independent, 6, 13 Junho 1878.

69. Helen Hunt Jackson, Bits of Travel at Home (Boston: Little Brown, and Co., 1898), p. 286.

70. Ibidem, p. 384.

71. Ibidem, p. 226. 
72. O tratamento mais longo da infância de Roosevelt gasto em busca de saúde pode ser encontrado em David McCullough, Mornings on Horseback (New York: Simon \& Schuster, 1981).

73. Sobre doenças da civilização, ver Charles Rosemberg, "Pathologies of Progress: The Idea of Civilization as a Risk," Bulletin of the History of Medicine (1998): 714-30.

74. Mary Douglas, Purity and Danger: an Analysis of Concepts of Pollution and Taboo (London: Routledge \& Kegan Paul, 1966).

75. Essa procura por purificação foi aliada com um nativismo insurgente que se espalhou pelas paisagens urbana e rural e pela natureza humana e não humana. Ainda precisamos juntar essas literaturas. Sobre alguns lugares iniciais, ver Susan Craddock, City of Plagues: Disease, Poverty, and Deviance in San Francisco (Minneapolis: University of Minnesota Press, 2000); Alan M. Kraut, Silent Travelers: Germs, Genes, and the "Immigrant Menace" (New York: Basic Books, 1994); Gregg Mitman, "When Pollen Became Poison: A Cultural Geography of Ragweed in America," em The Moral Authority of Nature, org. Daston e Vidal, 483-65; e Philip J. Pauly, "The Beauty and Menace of the Japanese Cherry Trees: Conflicting Visions of American Ecological Independence," Isis (1996): 51-73.

76. Mark David Spence, Dispossessing the Wilderness: Indian Removal and the Making of the National Parks (New York: Oxford University Press, 1999)

77. Carolyn Merchant, "Women of the Progressive Conservation Movement, 1900-1916," Environmental Review (1984): 57-85, explorou brevemente as conexões entre mulheres e a eugenia no Movimento Progressivo de Conservação. A relação entre conservação e eugenia também mereceu uma breve discussão em Ronald Rainger, An Agenda for Antiquity: Henry Fairfield Osborn \& Vertebrate Palentology at the American Museum of Natural History, 1890-1935 (Tuscaloosa: University of Alabama Press, 1991); e Susan R. Schrepfer, The Fight to Save the Redwoods: A History of Environmental Reform, 1917-1978 (Madison: University of Wisconsin Press, 1983). Ver também Gray Brechin, "Conserving the Race: Natural Aristocracies, Eugenics, and the U. S. Conservation Movement," Antipode (1996): 22945. Para alguns levantamentos historiográficos úteis da vasta literatura sobre a historia da eugenia na América, que também tem grandemente evitado as amarras da conservação, ver Philip Pauly, "Essay Review: The Eugenics Industry - Growth or Restructuring?" Journal of the History of Biology (1993): 131-45; e Frank Dikotter, "Race, Culture: Recent 
Perspectives on the History of Eugenics," American Historical Review (1998): 467-78.

78. Ver, por exemplo, Roger Pearson, "The Concept of Heredity in the History of Western Culture, Part I," Mankind Quarterly (1995):229-65.

79. Karl Jacoby, Crimes Against Nature: Squatters, Poachers, Thieves, and the Hidden History of American Conservation (Berkely e Los Angeles: University of California Press, 2001).

80. Proceedings of the Second National Conservation Congress at Saint Paul, September 5-8, 1910 (Washington, D.C.: National Conservation Congress, 1911), 275-76.

81. Kevin Dann, Across the Great Border Fault: The Naturalist Myth in American (New Brunswick, N. J.: Rutgers University Press, 2000), 143.

82. Citado em Dann, Across the Great Border Fault, 24-115.

83. Nicole Hahn Rafter, White Trash: The Eugenic Family Studies, 1877-1919 (Boston: Northeastern University Press, 1988).

84. O uso da natureza nos programas de reforma moral e física das instituições estaduais para as pessoas com problemas mentais ainda tem que ser escrito.

85. A questão da justiça, mais do que servir como uma divisão na história ambiental, poderia ser na verdade útil para trazer conhecimento às paisagens rural e urbano-industriais. Sobre história da justiça ambiental nos Estados Unidos, ver Robert Bullard, Dumping on Dixie: Race, Class and Environmental Quality (Boulder, Colo.: Westview Press, 1990); Giovana Di Chiro, "Nature as Community: The Covergence of Environmental and Social Justice," em Uncommon Ground: Rethinking the Human Place in Nature, org. William Cronon (New York: W. W. Norton, 1996), 298-321; Michael Egan, "Subaltern Environmentalism in the United States: a Historiographic Review," Environment and History (2002): 21-41; Gottlieb, Forcing the Spring; Dolores Greenberg, "Reconstructing Race and Protest: Environmental Justice in New York City," Environmental History (2000): 223-50; Eileen Maura McGurty, "From NIMBY to Civil Rights: The Origins of the Environmental Justice Movement," Environmental History (1997): 301-23; David Pellow, Garbage Wars: The Struggle for Environmental Justice in Chicago (Cambridge: MIT Press, 2002); and Laura Pulido, Environmentalism and Economic Justice: Two Chicano Struggles in the Southwest (Tucson: University of Arizona Press, 1996) 
86. Ver William Thomas, org., Man's role in changing the face of the earth (Chicago: University of Chicago Press, 1956). Uma história intelectual do campo, que nós desesperadoramente necessitamos, com certeza resgatará uma raiz da história ambiental até esse volume seminal. 